\title{
A Case of Ambiguous External Genitalia in a Thoroughbred Male Horse with the 63,XO/64,XY Mosaic Karyotype
}

\author{
Fumio SATO ${ }^{1,4) *}$, Keiichi HIROTA ${ }^{2)}$, Teruaki TOZAKI ${ }^{2)}$, Katsumi ITO ${ }^{3)}$, Pramod DHAKAL ${ }^{4)}$, Kazuyoshi TAYA ${ }^{5,6)}$, \\ Yoshiro ENDO') ${ }^{1)}$ Harutaka MURASE ${ }^{1)}$ and Yasuo $\mathrm{NAMBO}^{1,4)}$ \\ ${ }^{1)}$ Hidaka Training and Research Center, Japan Racing Association, 535-13 Nishicha, Urakawa, Hokkaido 057-0171, Japan \\ ${ }^{2}$ ) Department of Molecular Genetics, Laboratory of Racing Chemistry, 1731-2 Tsurutamachi, Utsunomiya, Tochigi 320-0851, Japan \\ ${ }^{3)}$ Hidaka Horse Breeders Association, 14 Nobuka, Urakawa, Hokkaido 059-3454, Japan \\ 4) Department of Clinical Veterinary Science, United Graduate School of Veterinary Sciences, Gifu University, 1-1 Yanagido, Gifu 501-1193, \\ Japan \\ 5) Laboratory of Veterinary Physiology, Department of Veterinary Medicine, Faculty of Agriculture, Tokyo University of Agriculture and \\ Technology, Fuchu, Tokyo 183-8509, Japan \\ ${ }^{6)}$ Department of Basic Veterinary Science, United Graduate School of Veterinary Sciences, Gifu University, 1-1 Yanagido, Gifu 501-1193, \\ Japan
}

(Received 24 October 2011/Accepted 11 May 2012/Published online in J-STAGE 25 May 2012)

ABSTRACT. A Thoroughbred colt with ambiguous external genitalia was presented for clinical and histological examinations. The colt had a short penis that faced backward between his hind limbs. The measurements of luteinizing hormone, follicle stimulating hormone, testosterone and ir-inhibin showed a tendency to increase gradually from April. Both the sex-determining region of the $\mathrm{Y}$ chromosome and amelogenin gene fragments were detected by the PCR method. A cytogenetic analysis revealed the 63,XO/64,XY mosaic karyotype (ratio 83:17). In autopsy, immature symmetrical subcutaneous testes were found in the inguinal regions. The testes and other accessory sex organs were histologically normal. These results add to our knowledge of chromosomal abnormality and information concerning disorders of sex development in the horse.

KEY WORDS: ambiguous genitalia, horse, mosaic karyotype.

doi: 10.1292/jvms.11-0473; J. Vet. Med. Sci. 74(10): 1327-1331, 2012

There are some reports on cytogenetic abnormalities found in an intersex horse $[2,4,5,13,22]$. Phenotypically normal mares having sex chromosome deviations such as a XY-female pseudohermaphroditism are usually discovered to be infertile, after they are offered for breeding with no estrus or streak gonads $[1,12,14,16]$. On the other hand, in natural and controlled selection of Thoroughbred horses, phenotypically abnormal individuals are excluded from breeding and reproduction, and these individuals are rarely exposed to chromosomal analysis [15]. Here, we report a clinical case of a Thoroughbred colt with ambiguous external genitalia. The subject was evaluated through endocrine hormone measurements, PCR amplification of the sexdetermining region of the $\mathrm{Y}$ chromosome (SRY) and amelogenin genes for sex chromosome detection, a karyotype analysis, and anatomical and histological examinations.

This study was conducted in accordance with the Approval and Guidelines of the Animal Welfare and Experiment Management Committee of the JRA Equine Research Center.

Animal: The present case was a Thoroughbred colt that

\footnotetext{
*Correspondence to: Sato, F., Hidaka Training and Research Center, JRA, 535-13 Nishicha, Urakawa, Hokkaido 057-0171, Japan. e-mail: Fumio_Sato@jra.go.jp

(C)2012 The Japanese Society of Veterinary Science
}

was the third foal of a 9-year-old dam that had given birth to 2 normal female offspring within 6 years and the offspring of a 15-year-old sire that had sired 137 male and 27 female offspring during 3 years in Japan. The colt was evaluated for this study from the age of 9 months, until he was euthanized at 13 months of age. The colt did not have any abnormality except an ambiguous penis that faced backward between his hind limbs (Fig. 1a and 1b). The penis was wrapped in a labium-like frenulum, which was visible only after the colt

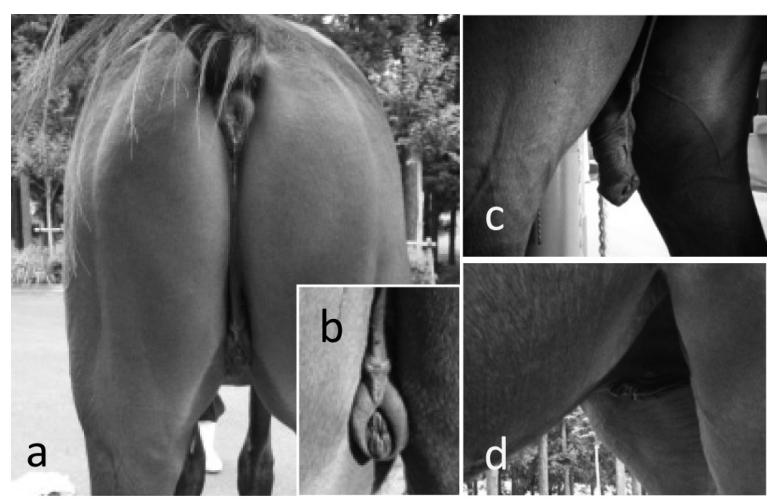

Fig. 1. The exterior appearance of the colt at 13 months old. The ambiguous genitalia faced backward (a). High magnification image of the ambiguous genitalia (b). The atrophic penis was revealed under sedation (from behind the colt) (c). The pellicle and nipples in the area of the lower abdominal region (d). 
was sedated with $5.0 \mu \mathrm{g} / \mathrm{kg}$ of medetomidine hydrochloride (Domitor ${ }^{\circledR}$, Nippon Zenyaku Kogyo Co., Ltd., Fukushima, Japan) administered intravenously (Fig. 1c). Then, an opening in the urethra duct was observed on the head of the atrophic penis (Fig. 1c). Additionally, a pellicle and nipples were observed on the lower abdominal region (Fig. 1d).

Endocrinological analysis: To investigate the levels of hormones secreted by the pituitary gland and the gonads during puberty, we collected plasma samples at approximately one-week intervals between 9 and 13 months of age (January to May). Luteinizing hormone ( $\mathrm{LH}$ ) and follicle-stimulating hormone (FSH) were determined by homologous doubleantibody equine RIA methods as described previously [17]. The intra- and interassay coefficients of variance were 12.6 and $15.1 \%$ for $\mathrm{LH}$, and 4.9 and $12.2 \%$ for FSH, respectively. Testosterone was determined by double-antibody RIA systems using ${ }^{125}$ I-labeled radioligands and antisera against testosterone (GDN 250) as previously described [20]. The intra- and interassay coefficients of variance were 6.3 and $7.2 \%$ for testosterone, respectively. Immunoreactive (ir-) inhibin was measured using a rabbit antiserum against purified bovine inhibin (TNDH 1) and ${ }^{125} \mathrm{I}-$ labeled 32-kDa bovine inhibin, as previously described [8]. The results were expressed in terms of $32-\mathrm{kDa}$ bovine inhibin. The intra- and interassay coefficients of variance were 8.0 and $16.2 \%$ for ir-inhibin, respectively.

The plasma concentrations of $\mathrm{LH}, \mathrm{FSH}$, testosterone and ir-inhibin started to increase gradually from April, as is seen in normal colt at prepuberty (Fig. 2).

PCR amplification for SRY and amelogenin: For sex chromosome detection, a simultaneous amplification of SRY gene and amelogenin genes was performed as previously described [9] with a genomic DNA sample prepared from peripheral blood of the colt. Additionally, one fertile mare and one fertile stallion were used as controls. DNA extraction was done according to the manufacturer's protocol (Wizard ${ }^{\circledR}$ Genomic DNA Purification Kit, Promega, Tokyo, Japan). The detection of PCR products was done by electrophoresis of $4 \%$ agarose gel in $20 \mathrm{mM}$ Tris-acetate and 0.5 mM EDTA. The gel was stained with ethidium bromide and photographed under UV light.

The case of the colt showed a band for the SRY gene and three amelogenin $\mathrm{X}$ and $\mathrm{Y}$ chromosome-related bands (Fig. 3).

Cytogenetic analysis: A blood sample was cultured for 70 hr using RPMI 1640 medium with 10\% FCS and 2\% pokeweed mitogen, and slides were prepared according to standard methods [11]. After staining with GTG (G-bands by trypsin using Giemsa) banding methods [14], 130 metaphases were observed for chromosome analysis.

The GTG banding method for chromosome identification revealed the $63, \mathrm{XO} / 64, \mathrm{XY}$ mosaic karyotype, the ratio being 83:17 (Fig. 4).

Anatomical and histological investigation: The colt was euthanized at 13 months of age, and its genital organs were dissected for anatomical examination. Samples from subcutaneous testes, epididymis, spermatic cord, accessory reproductive glands and a mammary-like gland were fixed in $10 \%$ buffered formalin and processed for histology, and slides were stained with hematoxylin and eosin stain.

The exterior appearance in the supine position is shown in Fig. 5a. A pellicle and nipples were observed on the lower abdominal region where the preputium was originally located. After decortication, we were able to confirm the presence of subcutaneous testes outside of the inguinal rings (Fig. 5b). The size of the left testis was $15 \times 6 \times 6 \mathrm{~cm}$, and right testis was $13 \times 5 \times 5 \mathrm{~cm}$. Under the pellicle, tissue like a mammary gland was also confirmed. Furthermore, the internal genitalia had normal pathological findings (Fig. $5 \mathrm{c}$ ). From the histological investigation of the subcutaneous testes, well-retained Sertoli cells and a spermatogonia with a round nucleus formed one or two layers in the seminiferous tubules (Fig. 6), similar to that found in a normal prepubertal male horse. Spermatogenesis was not observed in the seminiferous tubules, but large numbers of Leydig cells and fibroblast cells were observed in the inter-seminiferous tubules. Furthermore, the accessory glands (vesicular gland, prostate gland and bulbourethral gland) were also normal in terms of the histological findings (data was not shown). Additionally, the mammary-like gland consisted of only adipose tissue, and we did not recognize the glandular structure (data was not shown).

This is a first report on $63, \mathrm{XO} / 64, \mathrm{XY}$ mosaicism with ambiguous external genitalia and subcutaneous testes in the Thoroughbred colt. As far as we know, there are only two reports on $63, \mathrm{XO} / 64, \mathrm{XY}$ mosaicism in a Standardbred horse, a Quarter horse and an Appaloosa [5, 12]. The external genitalia in one of the Standardbred horses were also primarily male and not fully developed [5]. However, this was different from the case of a Standardbred colt having a small uterus and ovotestes in the urogenital fold and an urethral opening with a slit-like shape with thinning of the sides dorsally and ventrally, which was similar to a vulva. On the other hand, the Quarter horse and Appaloosa were phenotypically female and had clinical histories of infertility and small inactive ovaries [12]. In the present case, the Thoroughbred colt had only ambiguous external genitalia and subcutaneous testes.

The symmetrical subcutaneous testes were found in the inguinal regions after autopsy. If the scrotum does not exist, it must be considered that full testicular descent does not occur. Because we did not notice the existence of the testis before autopsy, it was important to carefully palpate the groin and a lower abdominal region for confirming the presence of subcutaneous testes under sedation. Because, medetomidine hydrochloride sedation has a relaxing effect on the equine penis, it is a useful method for discerning an ambiguous short penis and enlarged clitoris.

The endocrine hormone secretions of the colt were normal for a prepubertal male horse. The increase in the plasma concentrations of the hormones secreted from the testes or a pituitary gland indicated that the hypothalamic-pituitarygonadal axis was active as in a male horse. Histologically, a large number of Leydig cells and Sertoli cells were retained in the testes, whereas spermatogenesis was not observed. Generally, it is thought that spermatogenesis does not occur in retained testes (located in the abdomen, inguinal canal, 


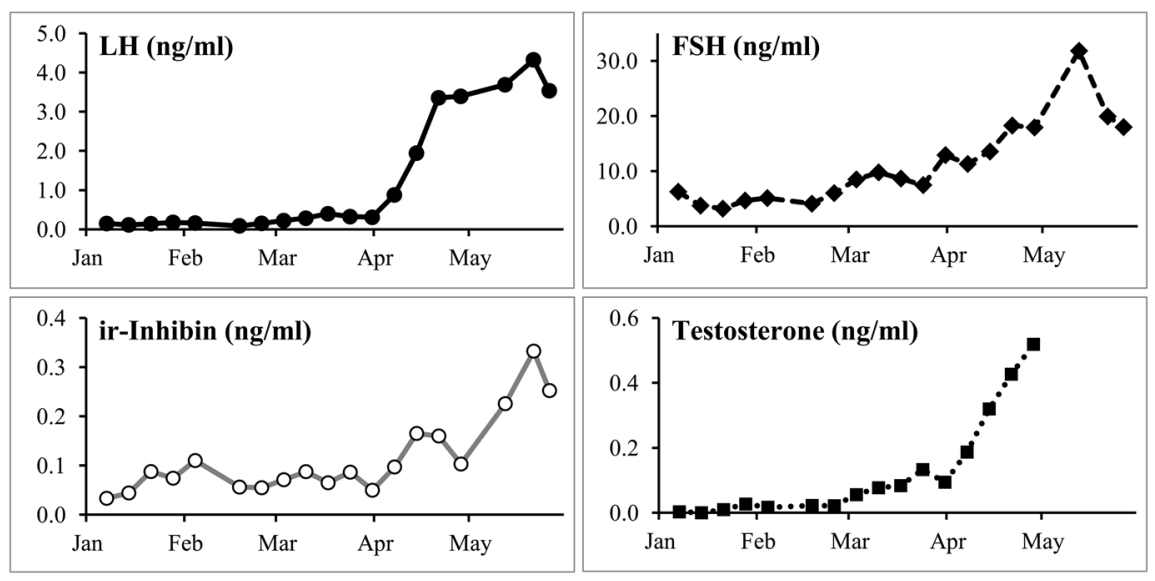

Fig. 2. Changes in the concentrations of circulating the pituitary hormones (LH, FSH, ir-Inhibin) and gonadal secretion hormone $(\mathrm{T})$ in the colt.

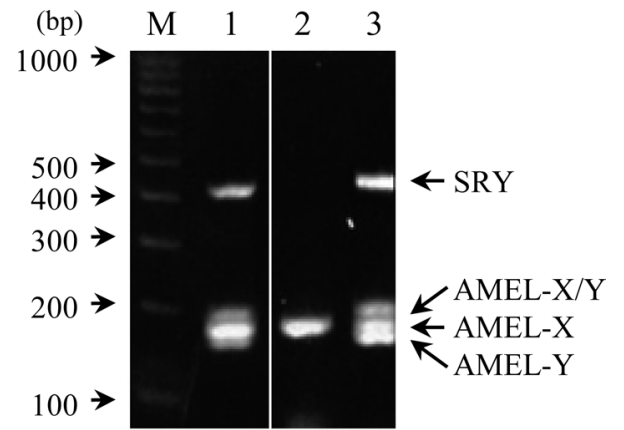

Fig. 3. Agarose gel electrophoresis for simultaneous PCR amplification of the equine SRY and amelogenin genes. The amelogenin (AMEL) gene analysis yielded 3 bands, an X-chromosome-derived product (AMEL$\mathrm{X}: 184 \mathrm{bp}$ ), Y-chromosome-derived product (AMELY: $160 \mathrm{bp}$ ) and heteroduplex product (AMEL-X/Y: less than $200 \mathrm{bp}$ ). An SRY fragment was found at 429 bp. Lane M: $100 \mathrm{bp}$ molecular marker. Lane 1: the case. Lane 2: fertile mare. Lane 3: fertile stallion.

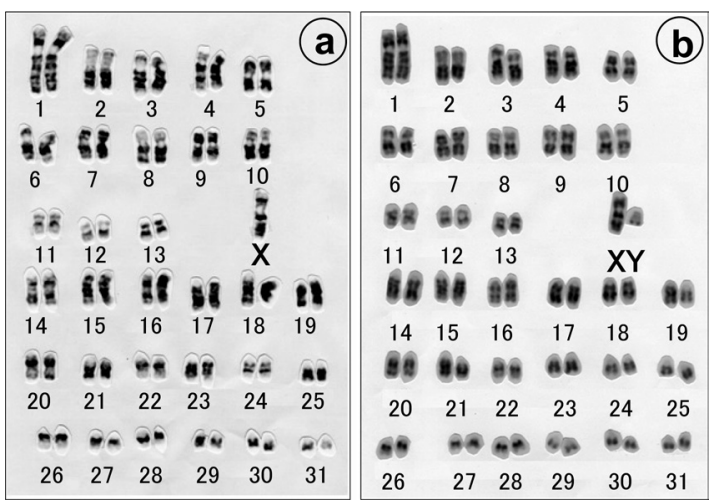

Fig. 4. Karyograms from peripheral blood leukocytes with the $63, \mathrm{XO}$ (a) and $64, \mathrm{XY}(\mathrm{b})$. The karyotype revealed that the $63, \mathrm{XO} / 64, \mathrm{XY}$ mosaic ratio was $83: 17$. X: X chromosome. Y: Y chromosome.
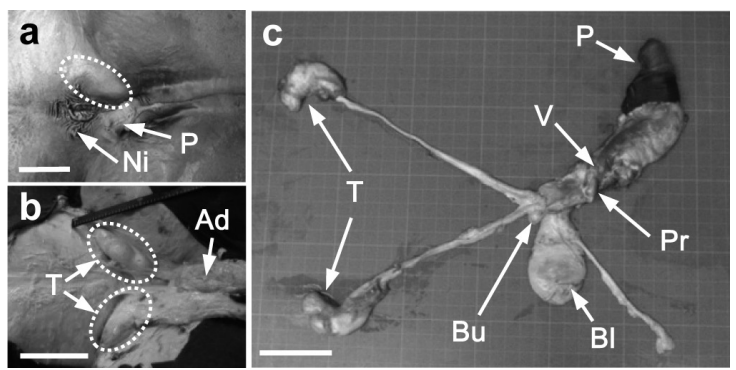

Fig. 5. Exterior appearance in the supine position (a) and after decortications (b) and pathological findings of internal genitalia (c). Ad: adipose tissue. Bl: bladder. Bu: bulbourethral gland. Ni: nipple. P: penis. Pr: prostate gland. T: subcutaneous testis (surrounded by dotted ovals). V: vesicular gland. $\mathrm{Bar}=20 \mathrm{~cm}$.
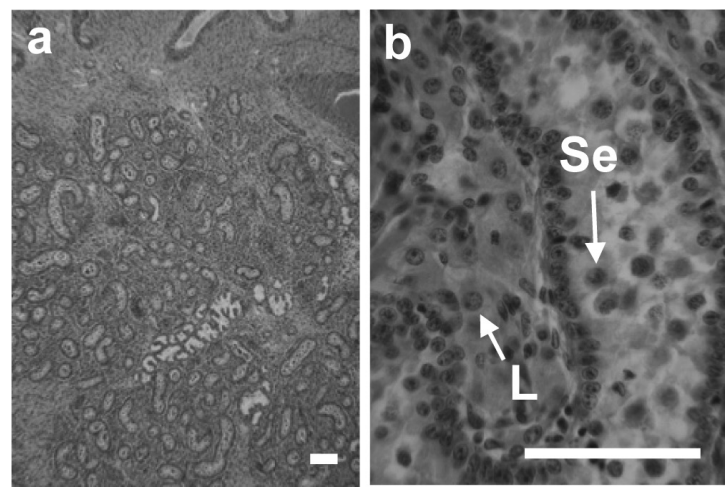

Fig. 6. Histological investigation of the testis (a). High magnification image of testis tissue (b). L: Leydig cells. Se: Sertoli cells in the seminiferous tubules. Bar $=100 \mu \mathrm{m}$.

subcutaneous tissue surrounding the external inguinal ring or near the neck of the scrotum), if they are nearer to the inside of the body. The spermatogenic cells of the colt might have decreased in the future, and the complete spermatogen- 
esis might not have been expected.

Simultaneous amplification of the SRY gene and amelogenin genes enables rapid diagnosis for determining the presence of both the $\mathrm{X}$ and $\mathrm{Y}$ chromosomes [9]. The simultaneous amplification method used in this study can reveal a single band of SRY product (a 429 bp product derived from the Y chromosome) and two different sizes of highly homogenous amelogenin products (AMEL-X, a 184 bp product derived from the $\mathrm{X}$ chromosome; AMEL-Y, a $160 \mathrm{bp}$ product derived from the $\mathrm{Y}$ chromosome) and a heteroduplex product of AMEL-X /AMEL-Y at less than 200 bp in electrophoresis, because the equine amelogenin amino acid coding sequence in exon-5 of the $\mathrm{Y}$ chromosome gene is 24 bases shorter than that of the $\mathrm{X}$ chromosome [7]. Hence, only one amelogenin band is present in electrophoresis in normal mares, but one SRY band and three amelogenin bands are often observed in abnormal mares having the Y chromosome. In the case of the present colt, we could immediately diagnose the presence of both the $\mathrm{X}$ and $\mathrm{Y}$ chromosome with peripheral leukocytes by amplifying a band for the SRY gene and three amelogeninrelated bands. Moreover, the cytogenetic analysis was able to reveal the $63, \mathrm{XO} / 64, \mathrm{XY}$ mosaic karyotype (ratio being $83: 17)$. The SRY gene controls the expression of SOX9 and plays an important role in internal and external genitalia development [6].Therefore, it was considered that the ambiguous external genitalia might have been caused by the SRY gene and other related gene expressions during early sex differentiation not being fully functional for the $63, \mathrm{XO} / 64, \mathrm{XY}$ mosaic karyotype.

In humans, the incidence of 45,XO/46,XY mosaicism was reported as 1.7/10,000 [3]. Normal male genitalia were found in $90 \%$ of cases of $45, \mathrm{XO} / 46, \mathrm{XY}$ mosaicism, whereas a wide spectrum of abnormalities of external or internal genitalia were detected in the remaining cases, such as a Turner syndrome $[10,18,21]$. The karyotype of $45, \mathrm{XO} / 46, \mathrm{XY}$ mosaicism is considered to be the loss by nondisjunction of the Y chromosome after normal disomic fertilization [19]. In the case of the Standardbred horse, it was mentioned that the $63, \mathrm{XO}$ cell could have arisen from anaphase lag and the loss of a Y or X chromosome from an XY or XX cell, and one blood cell was classified as 65,XXY [5]. It was thought that the $65, \mathrm{XXY}$ chromosomal karyotype proved an anaphase lag. In the case of the present colt, although the ratio of the $63, \mathrm{XO} / 64, \mathrm{XY}$ mosaic karyotype was $83: 17$ without the $65, \mathrm{XXY}$ cell line, the loss of a Y chromosome from a cell of an early $\mathrm{XY}$ embryo might have produced $\mathrm{XO} / \mathrm{XY}$ mosaicism.

Investigation of sex chromosomal aberrations in phenotypically abnormal male horses have been rarely conducted and reported. Cytogenetic and molecular biological analyses are very useful tools for diagnosis phenotypically abnormal and normal infertile horses. Such analysis methods will be more commonly used to study pseudohermaphroditism, and accumulation of this data will contribute to the knowledge base in veterinary medicine.

ACKNOWLEDGMENTS. We are grateful to Dr. Auli Makinen (University of Helsinki, Finland) for conducting the cytogenetic analysis and to Dr. Telhisa Hasegawa (formerly of the JRA Equine Research Center) for conducting the SRY and amelogenin PCR amplifications.

\section{REFERENCES}

1. Abe, S., Miyake, Y. I., Kageyama, S. I., Watanabe, G., Taya, K. and Kawakura, K. 1999. Deletion of the Sry region on the Y chromosome detected in a case of equine gonadal hypoplasia (XY female) with abnormal hormonal profiles. Equine Vet. J. 31: 336-338. [Medline] [CrossRef]

2. Bugno, M., Klukowska, J., Slota, E., Tischner, M. and Switonski, M. 2003. A sporadic case of the sex-reversed mare (64,XY; SRY-negative): molecular and cytogenetic studies of the Y chromosome. Theriogenology 59: 1597-1603. [Medline] [CrossRef]

3. Chang, H. J., Clark, R. D. and Bachman, H. 1990. The phenotype of 45,X/46,XY mosaicism: an analysis of 92 prenatally diagnosed cases. Am. J. Hum. Genet. 46: 156-167. [Medline]

4. Di Meo, G. P., Neglia, G., Perucatti, A., Genualdo, V., Iannuzzi, A., Crocco, D., Incarnato, D., Romano, G., Parma, P. and Iannuzzi, L. 2009. Numerical sex chromosome aberrations and abnormal sex development in horse and sheep. Sex Dev. 3: 329-332. [Medline] [CrossRef]

5. Dunn, H. O., Smiley, D., Duncan, J. R. and McEntee, K. 1981. Two equine true hermaphrodites with $64, \mathrm{XX} / 64, \mathrm{XY}$ and 63,XO/64,XY chimerism. Cornell Vet. 71: 123-135. [Medline]

6. Foster, J. W. and Graves, J. A. 1994. An SRY-related sequence on the marsupial X chromosome: implications for the evolution of the mammalian testis-determining gene. Proc. Natl. Acad. Sci. U.S.A. 91: 1927-1931. [Medline] [CrossRef]

7. Fukushima, Y., Mukoyama, H., Sato, F., Hasegawa, T., Ishida, N. and Muramatsu, S. 1999. Sex determination of equine somatic and germ cells by PCR amplification based on the sequence polymorphism of $\mathrm{X}$ - and Y-chromosomal amelogenin genes. Anim. Sci. J. 70: 6-10.

8. Hamada, T., Watanabe, G., Kokuho, T., Taya, K., Sasamoto, S., Hasegawa, Y., Miyamoto, K. and Igarashi, M. 1989. Radioimmunoassay of inhibin in various mammals. J. Endocrinol. 122: 697-704. [Medline] [CrossRef]

9. Hasegawa, T., Sato, F., Ishida, N., Fukushima, Y. and Mukoyama, H. 2000. Sex determination by simultaneous amplification of equine SRY and amelogenin genes. J. Vet. Med. Sci. 62: 1109-1110. [Medline] [CrossRef]

10. Hashimoto, H., Maruyama, H., Koshida, R., Okuda, N., Murayama, K., Katsumi, T., Watanabe, K. and Sato, T. 1997. Presence of Turner stigmata in a case of dysgenetic male pseudohermaphroditism with 45,X/46,X+mar karyotype. Arch. Dis. Child. 76: 268-271. [Medline] [CrossRef]

11. Hirota, K., Tozaki, T., Mashima, S. and Miura, N. 2001. Cytogenetic assignment and genetic characterization of the horse microsatellites, TKY4-18, TKY20, TKY22-24, TKY30-41 derived from a cosmid library. Anim. Genet. 32: 160-162. [Medline] [CrossRef]

12. Hughes, J. P. and Trommershausen-Smith, A. 1977. Infertility in the horse associated with chromosomal abnormalities. Aust. Vet. J. 53: 253-257. [Medline] [CrossRef]

13. Kakoi, H., Hirota, K., Gawahara, H., Kurosawa, M. and Kuwajima, M. 2005. Genetic diagnosis of sex chromosome aberrations in horses based on parentage test by microsatellite DNA and analysis of X-and Y-linked markers. Equine Vet. J. 37: 143-147. [Medline] [CrossRef]

14. Makinen, A., Hasegawa, T., Makila, M. and Katila, T. 1999. Infertility in two mares with XY and XXX sex chromosomes. 
Equine Vet. J. 31: 346-349. [Medline] [CrossRef]

15. Makinen, A. and Katila, T. 2004. Cytogenetic analysis as a tool for studying infertility in horse. J. Anim. Genet. 31: 41-46. [CrossRef]

16. Makinen, A., Suojala, L., Niini, T., Katila, T., Tozaki, T., Miyake, Y. and Hasegawa, T. 2001. X chromosome detection in an $\mathrm{XO}$ mare using a human $\mathrm{X}$ paint probe, and PCR detection of $\mathrm{SRY}$ and amelogenin genes in $3 \mathrm{XY}$ mares. Equine Vet. J. 33: 527-530. [Medline] [CrossRef]

17. Medan, M. S., Nambo, Y., Nagamine, N., Shinbo, H., Watanabe, G., Groome, N. and Taya, K. 2004. Plasma concentrations of ir-inhibin, inhibin A, inhibin pro-alphaC, FSH, and estradiol17 beta during estrous cycle in mares and their relationship with follicular growth. Endocrine 25: 7-14. [Medline] [CrossRef]

18. Oliveira, R. M., Verreschi, I. T., Lipay, M. V., Eca, L. P., Guedes, A. D. and Bianco, B. 2009. Y chromosome in Turner syndrome: review of the literature. Sao Paulo Med. J. 127: 373-378. [Medline] [CrossRef]
19. Robinson, W. P., Binkert, F., Bernasconi, F., Lorda-Sanchez, I., Werder, E. A. and Schinzel, A. A. 1995. Molecular studies of chromosomal mosaicism: relative frequency of chromosome gain or loss and possible role of cell selection. Am. J. Hum. Genet. 56: 444-451. [Medline]

20. Taya, K., Watanabe, G. and Sasamoto, S. 1985. Radioimuunoassay for progesterone, testosterone, and estoradiol-17b using ${ }^{125} \mathrm{I}-$ iodohistamic radioligand. Jpn. J. Anim. Reprod. 31: 186-197. [CrossRef]

21. Telvi, L., Lebbar, A., Del Pino, O., Barbet, J. P. and Chaussain, J. L. 1999. 45,X/46,XY mosaicism: report of 27 cases. Pediatrics 104: 304-308. [Medline] [CrossRef]

22. Villagomez, D. A., Lear, T. L., Chenier, T., Lee, S., McGee, R. B., Cahill, J., Foster, R. A., Reyes, E., St John, E. and King, W. A. 2011. Equine disorders of sexual development in 17 mares including XX, SRY-negative, XY, SRY-negative and XY, SRYpositive genotypes. Sex Dev. 5: 16-25. [Medline] [CrossRef] 